\title{
Social comparison and performance: Experimental evidence on the fair wage-effort hypothesis
}

\author{
Simon Gächter ${ }^{\mathrm{a}, \mathrm{b}, \mathrm{c}, *}$, Christian Thöni $^{\mathrm{d}}$ \\ a University of Nottingham, School of Economics, Sir Clive Granger Building, University Park, Nottingham NG7 2RD, United Kingdom \\ b CESifo, Munich, Germany \\ c IZA, Bonn, Belgium \\ d SEW-HSG, Varnbüelstrasse 14, CH-9000 St. Gallen, Switzerland
}

\section{A R T I C L E I N F O}

\section{Article history:}

Received 28 January 2010

Received in revised form 11 August 2010

Accepted 16 August 2010

Available online 24 August 2010

\section{JEL classification:}

$\mathrm{J} 31$

J71

C91

C92

\section{Keywords:}

Fair wage-effort hypothesis

Wage comparison

Gift exchange

Horizontal fairness

Wage discrimination

Labor market experiments

Strategy method

Individual heterogeneity

\begin{abstract}
A B S T R A C T
We investigate the impact of wage comparisons for worker productivity. We present three studies which all use three-person gift-exchange experiments. Consistent with Akerlof and Yellen's (1990) fair wage-effort hypothesis we find that disadvantageous wage discrimination leads to lower efforts while advantageous wage discrimination does not increase efforts on average. Two studies allow us to measure wage comparison effects at the individual level. We observe strongly heterogeneous wage comparison effects. We also find that reactions to wage discrimination can be attributed to the underlying intentions of discrimination rather than to payoff consequences.
\end{abstract}

(c) 2010 Elsevier B.V. All rights reserved.

\section{Introduction}

In a concept coined 'fair wage-effort hypothesis', Akerlof and Yellen (1990) stress the importance of fairness considerations for workers' effort choices. In labor relations where effort is not perfectly contractible workers' performance might depend on the perceived fairness of their salary. The core assumption of the fair wage-effort hypothesis is that workers compare their wage $w$ to the fair wage $w^{*}$. Effort is assumed to be increasing in $w$ as long as a worker's wage falls short of $w^{*}$; wage increases beyond $w^{*}$ do not increase effort further. In this paper, we investigate this hypothesis experimentally, using a three-person gift-exchange game as our work horse.

There is by now a large body of experimental evidence showing the importance of reciprocity in social exchange situations. Starting with Fehr et al. (1993), the literature on gift-exchange experiments shows that on average the effort of experimental

\footnotetext{
* Corresponding author at: School of Economics, Sir Clive Granger Building, University Park, Nottingham NG7 2RD, United Kingdom.

E-mail addresses: simon.gaechter@nottingham.ac.uk (S. Gächter), christian.thoeni@unisg.ch (C. Thöni).
} 
workers increases in the generosity of the wage offered by the employer. ${ }^{1}$ The existing experimental literature focuses largely on bilateral relations between an employer and a worker, or, in other words, on a 'vertical' comparison within a firm's hierarchy. Especially in real workplaces, however, it is most likely that Akerlof and Yellen's "fair wage" is to a large degree determined by 'horizontal' comparisons among employees. It is likely that people take their peers, that is, co-workers who are comparable to them, as a reference group for social comparisons (e.g., Falk and Knell, 2004; Clark and Senik, 2010). If social comparisons are important for work morale, internal pay structures (including wages, fringe benefits, and other perks) are important for performance. In the words of Bewley (1999) who interviewed more than 300 personnel managers: "The main function of internal structure is to ensure internal pay equity, which is critical for good morale" (p. 82). ${ }^{2}$

In this paper we investigate these morale effects using lab experiments. Laboratory experiments are suitable because they allow for the extensive control we need for answering our research questions (Falk and Heckman, 2009; Croson and Gächter, 2010). We concentrate on wage effects and use a three-person gift-exchange game (one employer, two employees) to measure the influence of wage differences on efforts. As common in gift-exchange experiments, effort is costly for employees but higher efforts increase total welfare. We are in particular interested in observing $e_{i}\left(w_{i}, w_{j}\right)$, where $e_{i}$ denotes worker $i$ 's effort as a function of his or her own wage $w_{i}$ and the wage of a co-worker, $w_{j}$. From previous experiments we predict that $\Delta e_{i} / \Delta w_{i}>0$, that is, on average employees react reciprocally to their own wage (despite material incentives to choose minimal effort irrespective of wages). The three-person gift-exchange experiment allows a direct measurement of $\Delta e_{i} / \Delta w_{j}$, that is, wage comparison effects-the average reaction of a worker's effort to an observed change in the co-worker's wage. Of particular interest for us are situations of 'pure' pay inequity, that is, inequitable situations that are not justified by situational differences, or differences in performance or merit, which equity theory (e.g., Adams, 1965; Konow, 2000) would predict are acceptable. In the cases we study, unequal pay is simply wage discrimination.

To answer our research question we conducted three studies. In Study 1 we use three-person gift-exchange games played in the usual sequential (direct response) mode. We repeat the basic three-person gift-exchange game eight times and randomly re-match groups of three players in each round. This is the simplest extension of the two-player game to allow for wage comparison effects. On average our experimental evidence supports Akerlof and Yellen's fair wage-effort hypothesis, if we assume that a worker takes the co-worker's wage as the reference wage. This assumption is plausible because in our experiment workers are identical, act in identical decision situations, and receive information only about their own and their current co-worker's wage. We find that experimental workers who face disadvantageous wage discrimination (that is, who are paid less than their colleague) significantly reduce their effort relative to a situation with equal wages.

In Study 1 we focus on average wage comparisons. In Study 2 we look at individual differences in wage comparison. Heterogeneity is interesting for at least three reasons. First, the theoretical solutions of our three-person gift-exchange game with social preferences allow for a wide range of patterns (see Thöni, 2009). Second, also empirically, heterogeneity is to be expected in our environment, given what we know from previous research on social preferences (see, e.g., Fehr and Fischbacher, 2002; Camerer and Fehr, 2006). Third, heterogeneity might also be a reason why some previous studies had difficulties finding wage comparison effects on the aggregate (e.g., Charness and Kuhn, 2007). If individual preferences go in different directions they might cancel each other out in the aggregate. Study 2 therefore investigates individual heterogeneity by using the strategy method to elicit effort reactions given all possible wage combinations. This has the advantage that we can elicit the entire wage-effort function, i.e., observe $e_{i}\left(w_{i}, w_{j}\right)$ for each individual and all possible wage combinations, not just those that happen to arise under the direct response method. The results show that the average effort reaction is again consistent with the fair wage-effort hypothesis. Yet, the average masks a large degree of heterogeneity. We observe a great variety of wage comparison patterns and provide a classification.

Finally, Study 3 explores whether wage comparison effects are due to intentional wage discrimination or due to payoff differences. This question is interesting, given recent evidence that fairness concerns are strongly influenced by perceived intentions (e.g., Falk et al., 2008). To test for the role of intentions we conduct an experiment where a random device chooses the wages. Thus, employers are not responsible for discriminatory wage arrangements. We find that the employer's intention to discriminate wages rather than mere payoff consequences triggers the wage comparison effects.

We see our experimental approach as complementary to other, more conventional empirical methods. The existing empirical studies paint a mixed picture about the consequences of wage inequality. ${ }^{3}$ We use laboratory experiments to cleanly isolate wage comparison effects from other confounding factors such as differential productivities and abilities. Our design allows us to observe morale effects directly. ${ }^{4}$ Moreover, if wage comparison effects are behaviorally important and can have negative morale effects as suggested by Bewley's quote, we might not be able to observe wage comparison effects easily in the field because naturally occurring wage structures are already designed to avoid negative morale effects.

\footnotetext{
1 See, for instance, Fehr et al. (1998); Hannan et al. (2002); Brandts and Charness (2004); Charness et al. (2004) and Charness (2004). For gift-exchange games with more than one employee see Maximiano et al. (2007). For recent overviews see Fehr et al. (2009) and Charness and Kuhn (forthcoming).

2 See, e.g., Agell and Bennmarker (2007) for similar findings. Clark and Oswald (1996) show that there is a significantly positive connection between an employee's relative income and job satisfaction. Loewenstein et al. (1989) provide a psychological account of inequality in social comparisons.

3 Some studies find that internal pay dispersion is detrimental for work morale and job performance (e.g., Grund and Westergaard-Nielsen, 2008), others fail to find that pay dispersion has any effect on employees' behavior (e.g., Leonard, 1990), and some studies even find that large pay differentials may have beneficial effects on firm performance (e.g., Winter-Ebmer and Zweimüller, 1999).

4 For a neuro-economic study on social comparisons that uses a similar methodology see Fliessbach et al. (2007).
} 
Thus, experiments allow us to investigate the counterfactual, which helps us to understand the importance of internal wage structures.

Our paper contributes to a nascent experimental literature on pay comparison effects. ${ }^{5}$ An early paper by Güth et al. (2001) investigates a trilateral principal-agent game where the two workers differ in productivity. The principal offers two separate contracts to the two workers. The treatment variable is the information workers receive about the contract of the other worker. The results show that contractual conditions are less asymmetric when workers can observe each others' contracts. Cabrales and Charness (2000) get a comparable result in a framework with asymmetric information (the principal does not know the type of his two agents). Our paper differs from these studies because our focus is not on contract design but on the agents' behavior. Charness and Kuhn (2007) lies closer to our goals. In contrast to Güth et al. (2001) they ran three-person gift-exchange games where experimental workers differ in their productivities. They do not find systematic wage comparison effects. ${ }^{6}$ Clark et al. (2010) study bilateral gift-exchange games where workers learn the attractiveness of their work contract relative to other contracts in the market. They show that the rank of the own wage within the wages in the observed contracts significantly influences efforts. Abeler et al. (forthcoming) look at a situation in which equality can also be unfair. To achieve this, they change the order of moves: agents first choose their efforts and the principal then decides (in one treatment) whether to pay equal or unequal wages (in a control treatment the principal is forced to pay equal wages). The results support equity theory, which in their case, often predicts unequal wages due to unequal efforts. ${ }^{7}$

Our study differs in two important aspects from all previous studies. Firstly, in our setup workers are employed by the same firm and they are ex ante in identical positions because they do not differ in their productivity at the time wages are set. Secondly, we are interested in individual heterogeneity and therefore offer two further experiments that allow us to discuss inter-individual differences.

\section{Design and procedures}

This section sets out the basic structure of the three-person gift-exchange game that is common to all three studies, which we describe in detail in Sections 3-5. In order to study the effect of wage comparisons among workers we adapt the standard bilateral gift-exchange game (Fehr et al., 1993). In particular, we study a three-person gift-exchange game in which an employer is matched with two workers. The game proceeds as follows. First, the employer chooses two wages $w_{i}$ and $w_{j}$ for worker $i$ and worker $j$, respectively. The employer is restricted to three wage levels: 10, 100, or 200 ECU (experimental currency units). The workers learn both wages and choose their effort $e_{i}, e_{j} \in\{1,2, \ldots, 20\}$ simultaneously. This concludes the game and earnings are calculated. The employer's income is

$$
\pi_{E}=18\left(e_{i}+e_{j}\right)-w_{i}-w_{j}
$$

We restrict the employers' choice to three wage levels to reduce the complexity in wage comparisons. Three wage levels are sufficient to study effort choices in situations where the co-worker earns less, the same, or more. The low wage allows the employer to earn a positive payoff with certainty, while higher wages bear the risk of negative payoffs. We expect most workers to choose the lowest effort when paid the lowest wage. These are not very interesting observations. However, the existence of a low wage is necessary to render the intermediate wage generous.

The production function is additively separable, that is, the two employees' efforts are perfect substitutes for the firm. We have chosen this simple way of aggregating the two efforts to total output deliberately since we want to examine the workers' wage-effort functions in a situation where the workers differ only with respect to the wage they receive. The income of a worker $i$ is given as

$$
\pi_{i}=w_{i}-c\left(e_{i}\right)=w_{i}-7\left(e_{i}-1\right) .
$$

Worker $j$ 's income is calculated according to the exact same payoff function. The workers receive their wage and have to bear the costs of their own effort. For ease of understanding costs are linear in effort and minimal effort is costless. The marginal product of effort is always higher than marginal cost which makes full effort the surplus-maximizing solution.

Solving the three-person gift-exchange game under standard assumptions results in minimal efforts and wages and thus predicts the absence of wage comparison effects. Introducing social preferences produces a large variety of possible patterns (see Thöni, 2009). This paper does not aim to test theories of social preferences but is designed to produce empirical facts about reactions to wage inequality in a stylized environment that is a straightforward (and most minimal) extension of the well-known two-player gift-exchange game to a three-person setting.

\footnotetext{
${ }^{5}$ A related literature using the gift-exchange game or similar games is on 'social interaction effects', that is, how the mere observation of others' behaviors influences own decisions. See Gächter et al. (2010), Mittone and Ploner (2009), and Thöni and Gächter (2010). For recent studies on social comparison effects using the ultimatum game see, e.g., Bohnet and Zeckhauser (2004) and Alewell and Nicklisch (2009).

${ }^{6}$ Hennig-Schmidt et al. (2010) found neither an own-wage nor a wage comparison effect in their field experiment. Subsequent laboratory experiments (which controlled only for own wage changes) revealed that the likely reason for the lack of an own-wage effect was that subjects in their field experiment did not receive any surplus information. Hence, attributions of fair or unfair treatment were hardly possible.

7 Another strand of literature studies wage comparison effects in real effort experiments or field experiments, where wage inequality is induced by the experimenter. See Burchett and Willoughby (2004), Cohn et al. (2009), and Greiner et al. (2010).
} 
We ran all experiments in a computerized laboratory at the University of St. Gallen (Switzerland) using $z$-Tree (Fischbacher, 2007); and we used ORSEE (Greiner, 2004) for recruitment. Our data for the three studies covers a total of 544 subjects. Subjects were first year students with no prior experience in gift-exchange games. Upon arrival the subjects were allocated at random to the computer terminals. The experimental instructions explained the rules of the experiment in detail (see online supplementary materials). The way we explained our three-person gift-exchange game is very similar to how previous studies explained the gift-exchange game. The subjects had to solve several exercises to prove their understanding of the task and the payoff functions. The experiment did not start before all subjects had answered all questions correctly. During the exercises and when making decisions subjects had access to a 'What-if-calculator'. This tool allowed the calculation of the payoff consequences for hypothetical values for $w_{1}, w_{2}, e_{1}$, and $e_{2}$. Before the experiment started, every subject had to calculate the three players' incomes for four exemplary wage and effort combinations. This procedure ensures familiarity with the 'What-if-calculator'. The participants used the 'What-if-calculator' frequently. On average they did 22 $(\sigma=16)$ calculations during the experiment. As in previous gift-exchange experiments (e.g., Fehr et al., 1997) we presented the experiment in a 'buyer-seller' frame, where buyers first choose two prices and the seller chooses the quality level of product. We chose this frame because we deem it to be a more conservative approach: with regard to our research question this frame is more neutral than a labor relations frame. ${ }^{8}$

The payoff functions (1) and (2) imply that the workers and the employer can make losses. In order to prevent overall losses, all subjects received a fixed payment of $400 \mathrm{ECU}$ at the beginning of the experiment. For the sessions with multiple rounds subjects were paid for one randomly selected round. Subjects earned on average $€ 9$ in this experiment. The experiments in Study 1 lasted about an hour; in Study 2 and Study 3 about half an hour.

\section{Study 1: the importance of wage comparison effects}

For Study 1 we conducted three experimental sessions with 36 subjects each. This provides us with observations from 36 employers and 72 workers, or 108 subjects in total. We repeat the game described in the previous section for eight rounds keeping roles constant and using a random matching protocol within matching groups of 12 subjects (that is, groups of three are randomly re-matched each period). We applied random matching to minimize strategic effects. The three sessions provide us with nine independent observations and a total of $8 \times 72=576$ effort choices. At the end of each round the employer is informed about the efforts of both employees. Each employee is, however, only informed about her own payoff, which minimizes potential confounding interaction effects among the two workers.

\subsection{Results}

The employers in our experiment paid on average a wage of 63 ECU. In 44 percent of the cases they offered the lowest possible wage combination (10;10); more generous symmetrical wage offers occurred in 19 percent of the cases with $(100 ; 100)$ and in 8 percent of the cases at (200;200). Asymmetric wage combinations occurred in 18 percent of the cases for $(10 ; 100$ or vice versa); in 6 percent for $(10 ; 200)$; and in 5 percent for $(100 ; 200)$. Asymmetric wage combinations were quite frequent. More than half of all wage offers (52 percent) with at least one non-minimal wage contained two different wages. ${ }^{9}$

On average, the employees reacted reciprocally towards increases in their own wage. At the lowest wage the average effort was 1.37, at the intermediate wage 4.75 and at the highest wage 6.58. A minority of 19.4 percent of the workers chose the minimal effort in all eight rounds of the experiment. When paid the minimal wage, most of the workers (72 percent) always chose the minimal effort. These observations are consistent with a host of previous gift-exchange experiments (see footnote 1).

Fig. 1 shows the average effort for all nine wage combinations. Connected dots show wage comparison effects, that is, the average efforts for a given own wage and for different co-worker's wages. Above the dots we indicate the number of observations for a given wage combination.

The wage comparison effects observed in this experiment do not seem to follow a clear pattern. At the minimum wage employees tend to increase their effort when the co-worker is paid a non-minimal wage. At the maximum wage employees tend to do the opposite, namely decrease their effort when the co-worker's wage is high or intermediate. The intermediate own wage of 100 is the most interesting one for comparison effects. Here we can observe the reaction to both advantageous and disadvantageous wage inequality. Earning more than the co-worker does not seem to affect efforts, while earning less than the co-worker leads to a substantial drop in average effort relative to the case when both workers earn a wage of 100.

\footnotetext{
${ }^{8}$ It is of course an empirical question whether framing matters in a gift-exchange context. Answering this question is beyond the scope of this paper. The existing evidence from a related game (the bribery game, which contains an element of reciprocity, see Abbink and Hennig-Schmidt, 2006) suggests that framing does not matter.

9 Paying different wages to ex ante identical workers and under a random matching protocol might seem odd. However, if workers differ in their reciprocal reaction to generous wages then paying a high wage is like a bet. Depending on his or her risk aversion an employer might prefer to play only one of the two available bets, i.e., paying only one of the two workers a generous wage.
} 


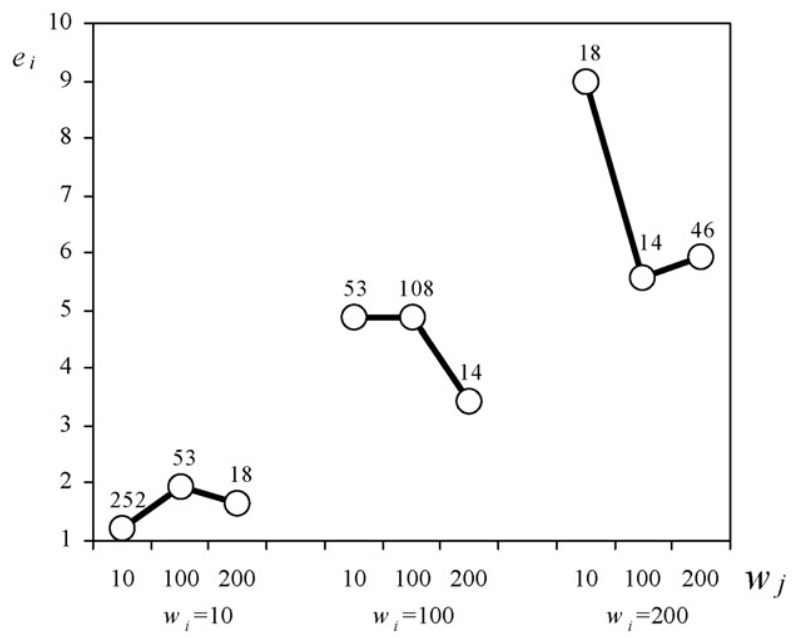

Fig. 1. Average efforts for all nine combinations of the own wage and the other employee's wage. Numbers indicate the number of observations for a given wage combination.

The question is whether these wage comparison effects are systematic. We use random-effects estimates to check for significant wage comparison effects, controlling for time effects and individual heterogeneity. We include wage variation by two dummies indicating the low and high wage, with the intermediate wage as omitted case. Model (1) in Table 1 shows that efforts are significantly increasing in the worker's own wage. We include two similar dummies for the other worker's wage. The dummy for $w_{j}=10$ is small and insignificant, on the other hand, the dummy for $w_{j}=200$ is much larger and marginally significant $(p=.099)$. The coefficient is negative, which means that employees tend to reduce their effort for a ceteris paribus increase of the co-worker's wage from 100 to 200. The estimate does not change if we include period effects (model (2)).

We apply additional estimates to investigate separate wage comparison effects in case a worker is paid the low, intermediate or high wage. The remaining models (3)-(5) in Table 1 show the results of random effects models for each of the three levels of a worker's own wage. These estimates correspond to a set of three line-connected dots in Fig. 1. The wage comparison effect at $w_{i}=100$ for a high co-worker's wage is highly significant. Workers do reduce their effort when they are paid less than their co-worker. Note that this is basically the only comparison that allows to measure employees' reactions to disadvantageous wage inequality, because in the situations with $w_{i}=10$ efforts are so low that most employees cannot react to changes in $w_{j}$.

To conclude, the reaction to disadvantageous wage inequality shown in Fig. 1 is highly significant when we control for period effects and individual heterogeneity. This is not the case for the pronounced drop at $w_{i}=200$, which remains insignificant in our estimates.

Table 1

Random effects GLS estimates for the effort choice, all observations and for the three levels of a worker $i$ 's wage.

\begin{tabular}{|c|c|c|c|c|c|}
\hline & \multicolumn{5}{|c|}{ Random effects GLS } \\
\hline & \multicolumn{2}{|l|}{ All obs } & \multirow{2}{*}{$\begin{array}{l}w_{i}=10 \\
(3)\end{array}$} & \multirow{2}{*}{$\begin{array}{l}w_{i}=100 \\
(4)\end{array}$} & \multirow{2}{*}{$\begin{array}{l}w_{i}=200 \\
(5)\end{array}$} \\
\hline & (1) & (2) & & & \\
\hline$w_{i}=10$ & $-3.675^{* *}(0.449)$ & $-3.553^{* *}(0.436)$ & & & \\
\hline$w_{i}=200$ & $2.474^{* *}(0.723)$ & $2.505^{* *}(0.745)$ & & & \\
\hline$w_{j}=10$ & $0.005(0.389)$ & $0.123(0.411)$ & $-0.667(0.404)$ & $0.316(0.299)$ & $2.203(1.570)$ \\
\hline$w_{j}=200$ & $-0.695(0.421)$ & $-0.665(0.405)$ & $-0.271(0.411)$ & $-1.225^{* *}(0.393)$ & $0.291(0.981)$ \\
\hline Period & & $-0.106^{*}(0.046)$ & $-0.060(0.049)$ & $-0.153(0.099)$ & $-0.251(0.215)$ \\
\hline Constant & $4.919^{* *}(0.271)$ & $5.253^{* *}(0.354)$ & $2.209^{* *}(0.472)$ & $5.447^{* *}(0.432)$ & $7.046^{* *}(1.366)$ \\
\hline prop $>\chi^{2}$ & 0.000 & 0.000 & 0.125 & 0.005 & 0.079 \\
\hline$N$ & 576 & 576 & 323 & 175 & 78 \\
\hline
\end{tabular}

In parentheses: robust standard errors clustered on matching group; the intermediate wages are the omitted cases.

* Denotes significance at 5 percent.

*** Denotes significance at 1 percent. 


\subsection{Discussion}

It is interesting to contrast our findings with those of Charness and Kuhn (2007) who also found a strong own-wage effect but little evidence for wage comparison effects. We find clear support for the importance of a wage comparison effect in the domain of disadvantageous wage inequality. ${ }^{10}$ The results for $w_{i}=100$ fit perfectly to the asymmetric pattern proposed by Akerlof and Yellen (1990), if we assume that the other worker's wage determines the reference wage. At $w_{i}=200$, where we only observe advantageous wage inequality, we cannot find systematic wage comparison effects.

While we allow for individual heterogeneity in efforts in our estimates, we still measure an average reaction to wage changes. However, it might well be the case that also these reactions to wage changes differ systematically across individuals. ${ }^{11}$ Furthermore, wage offers, and therefore also wage inequality, arise endogenously in this experiment, which implies that some wage combinations are quite rare and therefore individual reactions to different wage combinations are only observed infrequently and unequally across cells. Running the experiment for more rounds does not solve the problem because it might induce strategic confounds (due to unavoidable re-matchings) and still does not guarantee the collection of a sufficient number of observations in all the different wage combinations for all employees. In Study 2 we therefore replicate our three-person gift-exchange game using the strategy method for the workers' effort decisions. This will allow us to observe $e_{i}\left(w_{i}, w_{j}\right)$ for each individual, and not just some average $e_{i}\left(w_{i}, w_{j}\right)$.

\section{Study 2: the role of individual heterogeneity in wage comparison effects}

We use the exact same experimental game as in Study 1 with the exception that we elicit workers' efforts by a variant of the strategy method (Selten, 1967). As in the previous study employers decide on the wages but workers in this study choose their effort before they know the wages. Specifically, all workers have to fill in a $3 \times 3$ matrix to indicate an effort decision for every possible combination of their own wage and the wage of their co-worker. This information allows us to isolate the marginal effects of changes in the own wage and the wage of the other worker on the effort decision, that is, it allows us to observe the whole wage-effort function $e_{i}\left(w_{i}, w_{j}\right)$ at an individual level. After workers have decided on their efforts for all possible contingencies, payoffs are calculated given the actual wages the employers decided to pay. Unlike in Study 1 , subjects play the game only once in this study.

The strategy method is cognitively more demanding than the direct response mode since the subjects have to make choices for all possible situations. Therefore, we took great care to explain the procedure in detail. As in the previous study subjects had access to the 'What-if' calculator.

\subsection{Results}

We ran 12 sessions and observe 185 individual wage-effort functions. As in Study 1 employees on average reacted clearly positively to their own wage. ${ }^{12}$ At the lowest wage, employees chose an effort of 1.4 , at the intermediate wage the average effort was 5.0, and the high wage resulted in an average effort of 9.1 (see Fig. 2). Forty-seven of the 185 employees (25 percent) chose the own-payoff maximizing strategy (minimal effort in all nine cases). A majority of the employees (121 subjects, or 65 percent) chose a consistently reciprocal pattern, that is, given $w_{j}$, an increase of $w_{i}$ led to weakly higher efforts. Most of the remaining employees chose some non-monotonic strategy, while one employee chose a decreasing pattern.

Fig. 2 uses the same structure as Fig. 1 to illustrate average efforts at any given wage distribution. Here we do not display the number of observations because the strategy method gives us all 185 individual decisions for all wage combinations. For comparison we display the results of Study 1 by small dots. The overall degree of reciprocity towards the employer seems to be quite similar when we consider the low and the intermediate wage. For high wages $\left(w_{i}=200\right)$ we cannot confirm the large variation in the co-workers' wage observed in the direct response version of the game from Study 1 . At least for the two lower wage levels, where the vast majority of observations from Study $1 \mathrm{stem}$, the two elicitation methods seem to produce similar results. This supports the conclusion of a recent review of the literature on comparisons between the two elicitation methods (Brandts and Charness, 2009).

Concerning the most interesting case where employee $i$ earns the intermediate wage we now observe an inverted u-shaped influence of the co-worker's wage. Efforts were highest when both employees earned the intermediate wage,

\footnotetext{
10 One reason for the difference between Charness and Kuhn and our results might be the fact that in their experiment workers differed in productivity. This does not preclude that there are wage comparison effects, but the productivity differences certainly also play a role for effort reactions. Our results provide support for Charness and Kuhn's conjecture that equal productivities might lead to stronger wage comparison effects than the ones they actually observe (see Charness and Kuhn, 2007, footnote 12, p. 701).

11 Given the literature on heterogeneity with regard to reciprocal behaviour, one should also expect heterogeneity with regard to wage comparisons. The best explored area of individual heterogeneity is public goods experiments conducted with the strategy method. In these experiments subjects indicate how much they contribute as a function of others' contributions. The result is great heterogeneity: some are free rider types, whereas others reciprocate others' contributions. For recent literature see, e.g., Fischbacher and Gächter (2010); Herrmann and Thöni (2009); Muller et al. (2008) and Thöni et al. (2009). For an experiment using the strategy method in the gift-exchange game see Gächter et al. (2010).

12 In 33 percent of the cases employers chose (10;10); symmetric non-minimal wages were chosen in 27 percent for $(100 ; 100)$ and 9 percent for $(200$; $200)$ of the cases. Unequal wages were paid in 14 percent $(10 ; 100$ or vice versa); in 2 percent $(10 ; 200)$ and in 15 percent (100; 200) of the cases. As in Study 1 , once an employer chose to pay at least one non-minimal wage, unequal wages are observed in about half of the cases (47 percent).
} 


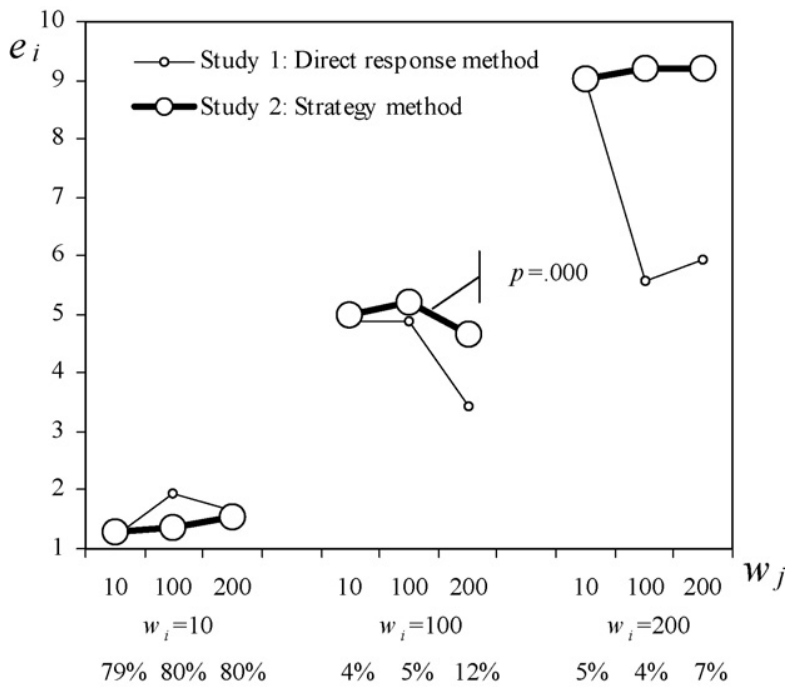

Fig. 2. The average wage-effort function of all employees $(n=185)$. $p$-Values are reported for significant wage comparison effects only ( $p<.1)$. Percentage numbers below the figure show for all wage combinations the percentage of subjects with minimal effort from all subjects who at least once chose non-minimal effort $(n=138)$.

decreased somewhat (by 0.22 effort units) when the other worker earned less and decreased more than twice as much (by 0.58 effort units) when the other worker earned more than worker $i$. This latter effect is significant at all conventional levels $(z=3.763, p=.000, n=185$, Wilcoxon matched-pairs signed-ranks test). All other comparisons of line-connected dots in Fig. 2 are insignificant with $p>.122 .{ }^{13}$

While the size of the wage comparison effect at the intermediate wage does not seem to be large (relative to reactions to changes in the worker's own wage) it is still a clear indication that, on average, people react negatively to disadvantageous wage discrimination. The comparison to the data from Study 1 suggests that average reactions to disadvantageous wage discrimination might be underestimated in Study 2 due to the use of the strategy method.

This result supports the existence of wage comparison effects in case of disadvantageous wage inequality. Recall that the significant effort differential is the only case where an employee can react to disadvantageous wage inequality. There are two other wage combinations where an employee is also in a disadvantageous situation, namely $\left(w_{i}, w_{j}\right)=(10,100)$ and $(10,200)$. However, even among the employees who chose non-minimal effort in at least one situation the vast majority (79 percent) could not lower the effort in this situation since they chose minimal effort already in the $(10,10)$ situation. The percentage number of subjects who chose minimal effort in a particular situation is indicated on the bottom line in Fig. 2 (the 25 percent of subjects who always chose minimal effort are excluded). Here we see additional support for the notion that being put in the disadvantageous situation influences the effort decision. The percentage number of employees choosing the lowest possible effort increased from 5 to 12 percent. This change is significant at $p=.007$ (McNemar test). In the domains of advantageous wage discrimination, where employee $i$ earns more than employee $j$, wage comparison effects are absent on average.

For a subset of subjects in the role of the employer we elicited their expectations about an employee's wage-effort function $(n=75)$. After they had chosen their wages we informed them that the experiment was over but asked them to fill in the same $3 \times 3$ matrix used for the employees. The results are very similar to the choice data: all but one wage comparison effects are insignificant. The comparison between $(100 ; 100)$ and $(100 ; 200)$ is of similar size as in Fig. 2 and significant at $p=.001$. Thus, the employers accurately anticipate the reaction to disadvantageous wage inequality (see the working paper version Gächter and Thöni, 2010 for more details).

\subsection{Heterogeneity}

The average wage-effort function shows evidence for wage comparison effects in the domain of disadvantageous wage inequality. In the domain of advantageous inequality, wage comparison effects do not seem to matter. However, it might be the case that the average wage-effort function hides interesting individual heterogeneity. This is in fact the case.

Among our 185 employees 47 (that is, 25 percent) chose minimal effort in all nine wage combinations. For these people own-payoff maximization apparently dominates any reciprocity or wage comparison effect. For the following analysis we

\footnotetext{
13 If we estimate wage comparison effects using the same model as in Table 1 (without Period) we obtain similar results: the comparison between (100,100) and $(100 ; 200)$ is highly significant $(p=.003)$, all other wage comparison effects are insignificant $(p>.1)$.
} 

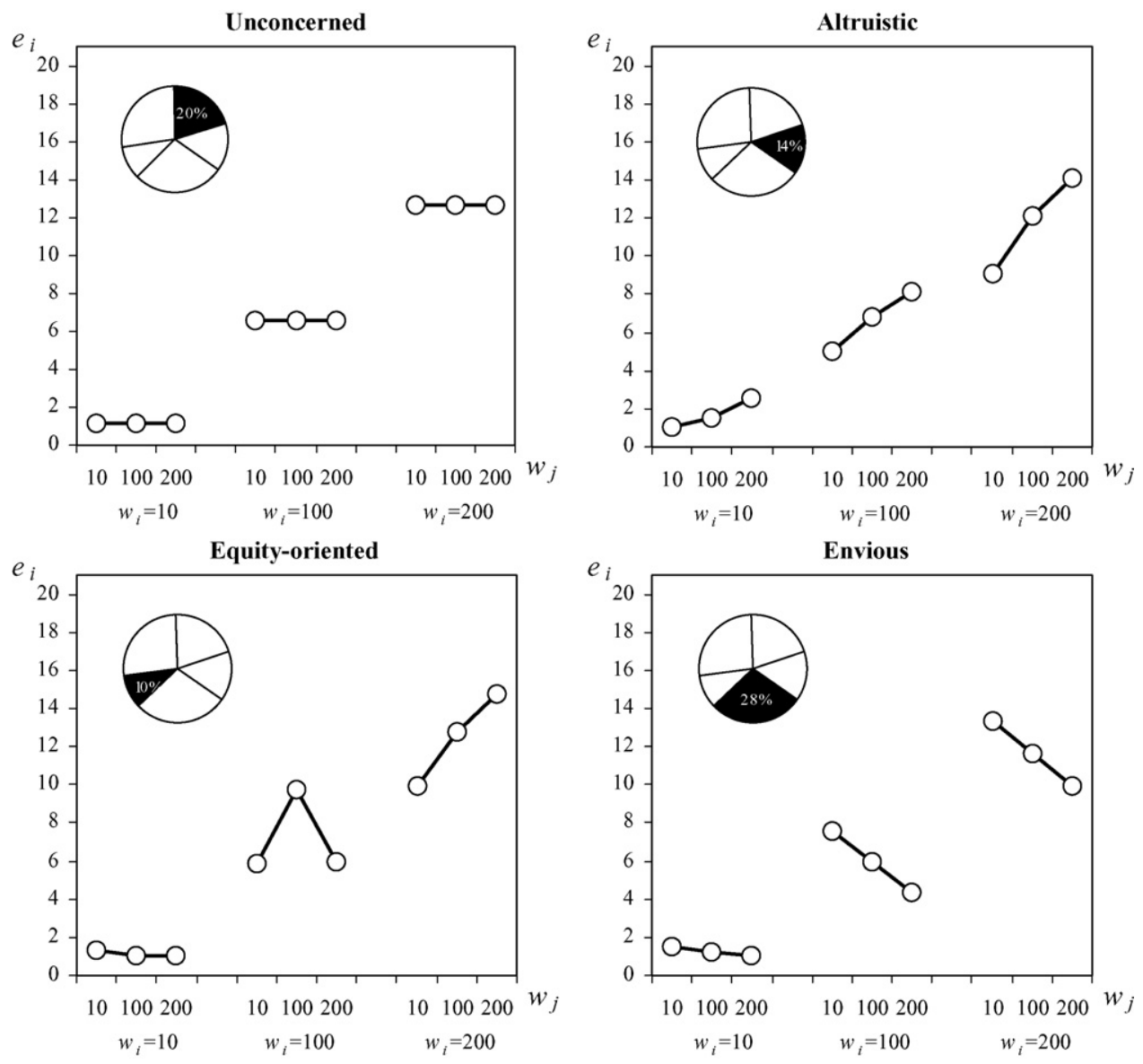

Fig. 3. Average wage-effort function of the four types of employees' behavior with some non-minimal efforts across different wage combinations.

therefore consider only the 138 observations with at least one non-minimal effort choice. We distinguish between four different patterns: (i) 20 percent of the employees do not differentiate their effort when the other employee's wage changes. We call this type of wage-effort function Unconcerned. (ii) Fourteen percent of the employees seem to reward their employer for a generous wage policy towards the other employee, that is, their effort is weakly increasing in $w_{j}$. We call this type of behavior Altruistic. (iii) As an opposite reaction to altruism we have employees who (weakly) decrease their effort with higher co-worker's wages. The 28 percent of the employees who exhibit such a pattern are called Envious. These three pattern account for 62 percent of the observations.

Among the remaining observations many show a hump-shaped pattern at a wage of 100 . Such a pattern can be interpreted as a preference for equal wages. An employee who, given the own wage, chooses a weakly higher effort in situations where the other employee has the same income is classified as Equity-oriented. Ten percent of our observations follow this pattern. ${ }^{14}$ The remaining 28 percent of the observations show different patterns. ${ }^{15}$ Fig. 3 shows the average wage-effort function separated by type.

The pie diagram shows the fraction of employees who chose a wage-effort function of the respective type. Interestingly, the average reaction to changes in an employee's own wage is very similar across the four types. This can be confirmed when comparing the average effort increase connected with an increase of the own wage. The hypothesis that the average

\footnotetext{
14 Note that the definitions Equity-oriented, and either Envious or Altruistic are not mutually exclusive. Our classification scheme favors Envious or Altruistic over Equity-oriented. If we would favor the Equity-oriented classification over the other two we could classify 16 percent of our observations as Equity-oriented.

15 When introducing a large number of types there is a potential danger of classifying noise into categories. We check whether the distribution of types observed in our experiment is systematic by comparing it to the distribution of types generated by random wage-effort functions. If we assume that efforts are chosen randomly the observed distribution of types is trivially different from randomly generated types due to the fact that in the latter case Unconcerned occur with virtually zero probability $\left(.05^{2}\right)^{3} \approx 0.000$. In a less restrictive scenario we allow for a systematic increase of effort in $w_{i}$. We assume that each worker chooses some intermediate $e_{i}$ whenever $w_{j}=100$ and then randomly decides to increase, decrease or leave unchanged the effort for every change in $w_{j}$ with equal probability. Also in such a simulation the probability of observing an Unconcerned is very small $p=\left((1 / 3)^{2}\right)^{3} \approx .0014$, which is still an order of magnitude away from what we observe in our experiment. A $\chi^{2}$-test of the simulated against the observed distribution of types yields $p=.000$, thus our wage comparison effects are clearly not random.
} 


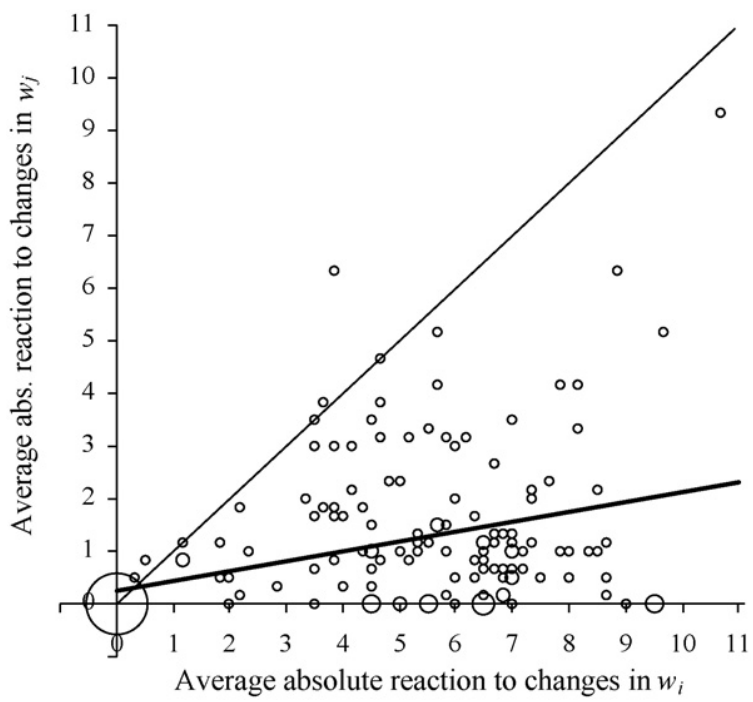

Fig. 4. Bubble plot of the intensity of the reaction to the own wage and to the wage of the other worker. The thin line is the 45 degree line, the thick line is the OLS regression line.

increase in effort of all four types stem from the same distribution cannot be refuted ( $p=.471$ for the step from $w_{i}=10-100$ and $p=.500$ for $100-200$, Kruskal-Wallis tests).

\subsection{Strength of wage comparisons}

Our analysis thus far showed that a majority of our subjects who at least once chose a non-minimal effort reacted in some way to the other worker's wage. Since the strategy method allows us to observe a complete wage-effort function for each individual we can also investigate how important, on average, reactions to own wages are relative to reactions to wage inequality. We calculate for every individual the average absolute reaction to ceteris paribus changes in both the own wage and the wage of the co-worker.

Fig. 4 shows how the two effects compare in strength. The size of bubbles is proportional to the number of underlying individuals. On the horizontal axis we denote the average reaction to a worker's own wage. On the vertical axis we depict the average reaction to changes in $w_{j}$. Both effects are measured in absolute average values.

Fig. 4 shows that almost all observations are below the 45 degree line, that is, the reaction to changes in a worker's own wage are stronger than reactions to the changes in the co-worker's wage. A few observations are on the $x$-axis, that is, these subjects only react to their own wage but not at all to the wage received by the co-worker. There is also a substantial number of observations at $0-0$. These subjects react neither to their own wage nor to their co-worker's wage.

The thick line depicts an OLS regression line, which indicates that reactions to $w_{i}$ and $w_{j}$ are positively correlated. The slope is .19 $(p=.000)$, which shows that on average reactions to the co-worker's wage are one-fifth of the average reaction to own wage.

\subsection{Discussion}

The results of Study 2 confirm the results of Study 1 in showing that there are significant wage comparison effects in the domain of disadvantageous wage discrimination. Consistent with the fair wage-effort hypothesis employees tend to reduce their effort when they are paid less than their co-worker but no equivalent effect is observed for overpayment. These average effects mask a surprisingly large variety of different patterns of wage comparison effects. Some workers seem to reward the employer for a generous wage for the co-worker, others do the opposite. These opposite sort of reactions can explain why on average wage comparison effects appear to be weak when in fact they are quite strong.

Why do we observe these wage comparison effects? In particular, what is the role of payoff differences relative to intentional wage discrimination, for wage comparison effects? Our Study 3 will address this question.

\section{Study 3: the role of intentional wage discrimination for wage comparison effects}

The goal of this study is to check whether the effort-reducing effect of disadvantageous wage inequality stems from aversion to intentional discrimination. Experimental and theoretical research on social preferences suggest that in addition to payoff comparisons intentions play a substantial role (e.g., Blount, 1995; Dufwenberg and Kirchsteiger, 2000; Falk et al., 


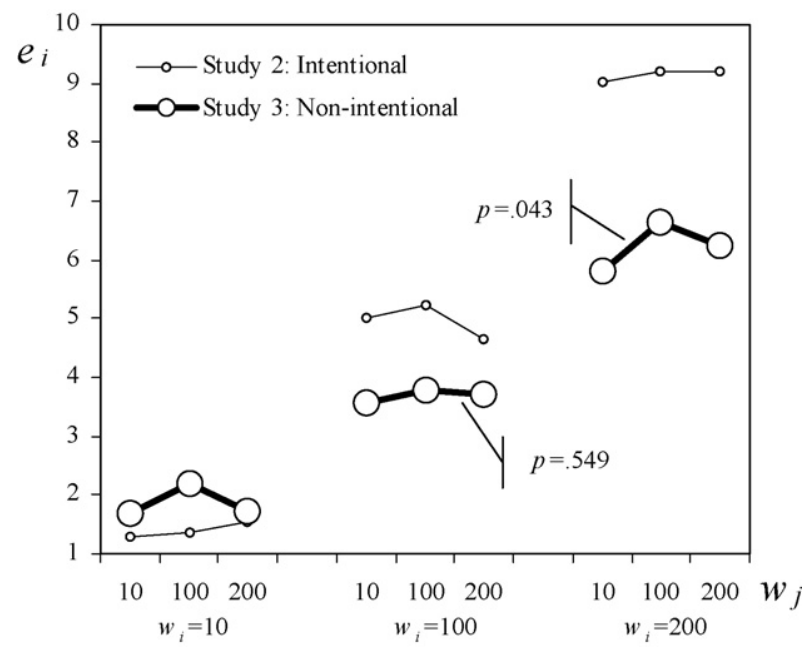

Fig. 5. Average wage-effort function in the Non-intentional treatments of Study 3 and the results of Study 2 for comparison. $p$-Values show the significance of wage comparison effects between the adjacent wage combinations. All other wage comparison effects are insignificant ( $p>.1$ ).

2003; Charness, 2004; Falk and Fischbacher, 2006; Falk et al., 2008). Therefore, effort reactions might be different if the wage offers are not the deliberate choice of the employer.

We ran three additional sessions with a non-intentional variant of our three-person gift-exchange games. The experiment is exactly the same as in Study 2 with the exception that the employer does not choose the wages. Instead, a random device chooses the two wages on behalf of the employer, who does not make any decision (for similar designs see Blount, 1995; Charness, 2004; Falk et al., 2008). The probabilities for each of the nine wage combinations are chosen to match the frequencies of wage offerings observed in Study 2. All subjects were informed about this procedure.

What should we expect from such a Non-intentional treatment? Workers presumably choose lower efforts in the case of disadvantageous wage inequality in order to express their discontent with the situation. If the employer is not responsible for wage inequality, there is no reason to punish him for unequal wages. We therefore expect the wage comparison effects to disappear in the experiments of Study 3. We also expect a reduced own-wage effect, in particular for non-minimal wages, because attributed kindness, in addition to payoff comparisons has been shown to be important in gift exchange (Charness, 2004; Falk and Fischbacher, 2006).

\subsection{Results}

We observe the wage-effort functions of 70 employees. Fig. 5 shows the average wage-effort function of the Nonintentional treatments. For comparison we also show the results from Study 2. Similar to Charness (2004) we find that removing the 'intentionality' behind the wage offer reduces the strength of the reaction to wage changes. Low wages induce slightly higher efforts and high wages induce lower efforts relative to the case with intentional wage offers. Especially in the latter case our data shows stronger effects between the Intentional and the Non-intentional treatment than those found by Charness (2004). The average effort in all nine wage combinations is 5.2 in Intentional versus 3.9 in Non-intentional. This difference is significant at all conventional levels. ${ }^{16}$

The drop in efforts in case of disadvantageous wage inequality at intermediate wages disappears almost entirely. The tiny decrease of .07 effort units is insignificant and so is a McNemar's test for the probability of choosing a minimal effort between the $\left(w_{i}, w_{j}\right)=(100,100)$ and $(100,200)$ situations. All differences between the line-connected dots in Fig. 5 are insignificant at $p>.138$, with the exception of the increase between $\left(w_{i}, w_{j}\right)=(200,10)$ and $(200,100)$. This comparison is significant at $p=.043$. Increasing one's effort when the co-worker's wage increases from 10 to 100 makes sense if a worker thinks that he should compensate the employer for being forced (by chance) to be generous to the other worker. However, it is unclear why this effect should be reversed when the co-worker's wage goes from 100 to 200 . So overall the hump-shaped pattern at $w_{i}=200$ is difficult to explain and we suspect that it does not reflect an important behavioral regularity. We conclude that removing the intentional aspect of disadvantageous wage discrimination does eliminate its effort-reducing effects in case of disadvantageous wage inequality.

\footnotetext{
${ }^{16}$ A two-sample Wilcoxon rank-sum test returns $p=.002$. This is partly due to the fact that a higher fraction of the subjects ( 37 percent) chose minimal effort in all nine wage combinations. In Study 2 we observed 25 percent. The difference is weakly significant by a two-sided Fisher exact test $(p=.087)$. However, even if we consider only the subjects with at least one non-minimal effort the difference between the two treatments in average efforts remains significant with $p=.005$.
} 


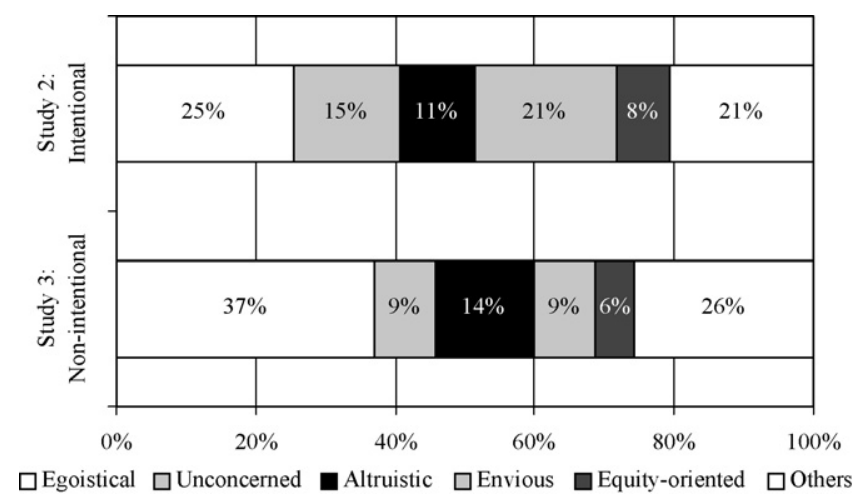

Fig. 6. Distributions of types of wage-effort functions in the Non-intentional and the Intentional treatment.

\subsection{Heterogeneity}

The fact that wage comparison effects disappear for the intermediate wage suggests that the change from the intentional to the non-intentional treatment also affects the distribution of types of wage-effort functions in the population. Fig. 6 shows the percentage of each type of wage-effort function in the Intentional and Non-intentional treatment. Unlike in Fig. 3 we now include observations from subjects choosing minimal effort in all nine situations, and coin them as Egoistical. Given that average efforts in Non-intentional were substantially below average efforts in Intentional it is not surprising that the percentage of Egoistical patterns is much larger in the former. Removing intentional wage payments leads to an increase in Altruistic types (from 11 to 14 percent). The other three types occur less frequently. Especially pronounced is the drop in Envious types (21-9 percent).

Overall the differences in the distribution of types is only weakly significant (Pearson $\chi^{2}(5)=9.69, p=.085$ ). However, if we focus on two specific types where workers systematically punish the employer for disadvantageous wage inequality (Envious and Equity-oriented) we observe a combined drop from 29 to 15 percent when intentions are removed. If we test these two types against the remaining observations we observe a significant difference $\left(\chi^{2}(1)=5.27 ; p=0.022\right)$. This clearly indicates that if we remove the intentionality behind wage discrimination the adverse effect of the co-worker's wage on a worker's effort is substantially reduced.

\subsection{Discussion}

The results of Study 3 show that it is the intentional aspect of wage discrimination that produces the effort reduction in case of disadvantageous wage discrimination and not pure payoff comparisons. On the other hand, when wage inequality is non-intentional, we observe slightly more Altruistic types, indicating that workers tend to compensate the employer not only for being forced to pay themselves a high wage but also for being forced to pay the co-worker a high wage. This makes sense if the driving force behind wage comparison effects is interdependent preferences (Sobel, 2005). For the Intentional treatments observed behavior is likely to be explained by a mix of interdependent preferences and reciprocal motives, leading to much more adverse reactions to unfavorable wage discrimination. ${ }^{17}$

We conclude that randomly generated wages do not give rise to the effort-reducing effect in case of disadvantageous wage discrimination. In terms of the fair wage-effort hypothesis it seems that the other worker's wage loses its role of a reference wage if it is not determined intentionally by the employer. Consistent with previous evidence (e.g., Charness, 2004) payoff concerns do matter with regard to own wages-higher wages induce higher efforts, although at a lower level than in the intentional treatment of Study 2 . The reciprocal reaction to one's own wage is substantially reduced if wage payments are not intentional. ${ }^{18}$

\section{Concluding remarks}

The results from laboratory experiments reported in this paper support the view that wage comparison is an important determinant for a worker's effort decision. We find strong wage comparison effects both in the three-person gift-exchange

\footnotetext{
17 Pure reciprocity models like Dufwenberg and Kirchsteiger (2004) cannot explain wage comparison effects due to the fact that the kindness terms in these models solely depend on a worker's own (hypothetical) income. Explaining wage comparison effects would require a kindness dependent on how the employer treats the other worker. See Thöni (2009) for details.

18 The more general point is that attributions to wage payments matter. In a lab environment, through its extensive control and payoff information, attributions are probably less ambiguous than in some field contexts and may thereby explain why some field experiments observe less gift exchange than lab experiments (see, e.g., Gneezy and List, 2006). See also Falk (2007); Hennig-Schmidt et al. (2010); and Kube et al. (2010) for discussions and further experiments on the role of attributions for gift exchange.
} 
game in the direct response mode (Study 1) and when we use the strategy method (Study 2). Consistent with Akerlof and Yellen's fair wage-effort hypothesis (Akerlof and Yellen, 1990) we observe in both Study 1 and Study 2 that paying a worker less than his co-worker leads to a decrease in effort relative to a situation with equal wages. Paying a worker more than a co-worker does not increase effort levels on average. Study 3 revealed that the overall wage comparison effects are due to an aversion to intentional wage discrimination, and not due to resulting payoff differences. Study 3 not only showed the importance of intentions for reactions to wage discrimination but also for the strength of gift exchange.

A main result of our paper is that there is a large degree of individual heterogeneity in our data. We observe several patterns: some workers do not react at all to changes in the co-worker's wage, some increase or decrease their effort for changes in the co-worker's wage, and a fourth category chooses highest effort whenever the two wages are equal. Despite the high degree of heterogeneity, the observed wage comparison effects are clearly not random. In the case of advantageous wage discrimination the heterogeneous effects seem to counterbalance each other, leading to no systematic overall effect. In case of disadvantageous wage inequality the overall effect is clearly negative.

We see our experiment as a test for the existence of wage comparison effects: subjects in the role of the worker have no information about the reasons for wage discrimination and they take their decision under anonymity. We conjecture that our laboratory measure of wage comparison effects provide a lower bound for the importance of wage comparison effects in more naturally occurring environments. This conclusion is suggested by a recent field experiment by Cohn et al. (2009) who, consistent with our findings, report strong behavioral reactions to wage inequality.

\section{Acknowledgements}

This paper is part of a research project "Soziale Interaktionen, Unternehmenskultur and Anreizgestaltung", financed by the Grundlagenforschungsfonds of the University of St. Gallen. We are grateful for very helpful comments by George Akerlof, Daniele Nosenzo, Therese Fässler, Martin Sefton, and the seminar and workshop participants in Montreal, Nottingham, Paris, St. Gallen, Stockholm, and Zürich. Simon Gächter also gratefully acknowledges the hospitality of the Institute for Advanced Studies at Hebrew University in Jerusalem while working on this paper.

\section{Appendix A. Supplementary data}

Supplementary data associated with this article can be found, in the online version, at doi:10.1016/j.jebo.2010.08.008.

\section{References}

Abbink, K., Hennig-Schmidt, H., 2006. Neutral versus loaded instructions in a bribery experiment. Experimental Economics 9, $103-121$.

Abeler, J., Altmann, S., Kube, S., Wibral, M., forthcoming. Reciprocity and payment schemes: when equality is unfair. Journal of the European Economic Association.

Adams, J.S., 1965. Inequity in social exchange. In: Adams, J.S. (Ed.), Advances in Experimental Psychology. Academic Press, New York, pp. 267-299.

Agell, J., Bennmarker, H., 2007. Wage incentives and wage rigidity: a representative view from within. Labour Economics $14,347-369$.

Akerlof, G.A., Yellen, J.L., 1990. The fair wage-effort hypothesis and unemployment. Quarterly Journal of Economics 105, $255-283$.

Alewell, D., Nicklisch, A., 2009. Wage differentials and social comparison: an experimental study of interrelated ultimatum bargaining. International Review of Law and Economics 29, 210-220.

Bewley, T., 1999. Why Wages Don't Fall in a Recession. Harvard University Press, Cambridge.

Blount, S., 1995. When social outcomes aren't fair-the effect of causal attributions on preferences. Organizational Behavior and Human Decision Processes $63,131-144$.

Bohnet, I., Zeckhauser, R., 2004. Social comparisons in ultimatum bargaining. Scandinavian Journal of Economics $106,495-510$.

Brandts, J., Charness, G., 2004. Do labour market conditions affect gift exchange? Some experimental evidence. Economic Journal $114,684-708$.

Brandts, J., Charness, G., 2009. The Strategy Method: A Survey of Experimental Evidence. Mimeo, Department of Business Economics U, Autònoma de Barcelona and Department of Economics, UC Santa Barbara.

Burchett, R., Willoughby, J., 2004. Work productivity when knowledge of different reward systems varies: report from an economic experiment. Journal of Economic Psychology 25, 591-600.

Cabrales, A., Charness, G., 2000. Optimal contracts, adverse selection, and social preferences: an experiment. Universitat Pompeu Fabra Working Paper No. 478.

Camerer, C.F., Fehr, E., 2006. When does ‘economic man’ dominate social behavior? Science 311, 47-52

Charness, G., 2004. Attribution and reciprocity in an experimental labor market. Journal of Labor Economics 22, 665-688.

Charness, G., Frechette, G.R., Kagel, J.H., 2004. How robust is laboratory gift exchange? Experimental Economics 7, $189-205$.

Charness, G., Kuhn, P., 2007. Does pay inequality affect worker effort? Experimental evidence. Journal of Labor Economics 25, 693-723.

Charness, G., Kuhn, P., forthcoming. Lab labor: what can labor economists learn from the lab? In: Ashenfelter, O., Card, D. (Eds.), Handbook of Labor Economics, vol. 4. Elsevier, Amsterdam, Available at http://ftp.iza.org/dp4941.pdf.

Clark, A., Masclet, D., Villeval, M.C., 2010. Effort and comparison income: experimental and survey evidence. Industrial and Labor Relations Review 63, 407-426.

Clark, A.E., Oswald, A.J., 1996. Satisfaction and comparison income. Journal of Public Economics 61, 359-381.

Clark, A.E., Senik, C., 2010. Who compares to whom? The anatomy of income comparisons in Europe. The Economic Journal $120,573-594$.

Cohn, A., Fehr, E., Herrmann, B., Schneider, F., 2009. Social Comparison in the Workplace: Evidence from a Field Experiment. Mimeo, Institute for Empirical Research in Economics, University of Zurich.

Croson, R., Gächter, S., 2010. The science of experimental economics. Journal of Economic Behavior \& Organization 73, $122-131$.

Dufwenberg, M., Kirchsteiger, G., 2000. Reciprocity and wage undercutting. European Economic Review 44, 1069-1078.

Dufwenberg, M., Kirchsteiger, G., 2004. A theory of sequential reciprocity. Games and Economic Behavior 47, $268-298$.

Falk, A., 2007. Gift exchange in the field. Econometrica 75, 1501-1511.

Falk, A., Fehr, E., Fischbacher, U., 2003. On the nature of fair behavior. Economic Inquiry 41, 20-26.

Falk, A., Fehr, E., Fischbacher, U., 2008. Testing theories of fairness-intentions matter. Games and Economic Behavior 62, $287-303$.

Falk, A., Fischbacher, U., 2006. A theory of reciprocity. Games and Economic Behavior 54, 293-315. 
Falk, A., Heckman, J.J., 2009. Lab experiments are a major source of knowledge in the social sciences. Science 326, 535-538.

Falk, A., Knell, M., 2004. Choosing the Joneses: endogenous goals and reference standards. Scandinavian Journal of Economics 106, $417-435$.

Fehr, E., Fischbacher, U., 2002. Why social preferences matter-the impact of non-selfish motives on competition, cooperation and incentives. Economic Journal 112, C1-C33.

Fehr, E., Gächter, S., Kirchsteiger, G., 1997. Reciprocity as a contract enforcement device: experimental evidence. Econometrica 65, 833-860.

Fehr, E., Goette, L., Zehnder, C., 2009. A behavioral account of the labor market: the role of fairness concerns. Annual Review of Economics 1, $355-384$.

Fehr, E., Kirchler, E., Weichbold, A., Gächter, S., 1998. When social norms overpower competition: gift exchange in experimental labor markets. Journal of Labor Economics 16, 324-351.

Fehr, E., Kirchsteiger, G., Riedl, A., 1993. Does fairness prevent market clearing? An experimental investigation. Quarterly Journal of Economics 108, 437-459.

Fischbacher, U., 2007. Z-tree: Zurich toolbox for readymade economic experiments. Experimental Economics 10, 171-178.

Fischbacher, U., Gächter, S., 2010. Social preferences, beliefs, and the dynamics of free riding in public good experiments. American Economic Review 100, $541-556$.

Fliessbach, K., Weber, B., Trautner, P., Dohmen, T., Sunde, U., Elger, C.E., Falk, A., 2007. Social comparison affects reward-related brain activity in the human ventral striatum. Science 318, 1305-1308.

Gächter, S., Nosenzo, D., Sefton, M., 2010. The impact of social comparisons on reciprocity. CeDEx Discussion Paper No. 2010-10, University of Nottingham.

Gächter, S., Thöni, C., 2010. Social comparison and performance: experimental evidence on the fair-wage effort hypothesis. CeDEx Discussion Paper No. 2009-23, University of Nottingham.

Gneezy, U., List, J.A., 2006. Putting behavioral economics to work: testing for gift exchange in labor markets using field experiments. Econometrica 74, 1364-1985.

Greiner, B., 2004. An online recruitment system for economic experiments. In: Kremer, K., Macho, V. (Eds.), Forschung und Wissenschaftliches Rechnen GWDG Bericht 63. Gesellschaft für Wissenschaftliche Datenverarbeitung, Göttingen, pp. 79-93.

Greiner, B., Ockenfels, A., Werner, P., 2010. Wage transparency and performance: a real-effort experiment. University of Cologne, Working Paper Series in Economics, No. 48

Grund, C., Westergaard-Nielsen, N., 2008. The dispersion of employees' wage increases and firm performance. Industrial and Labor Relations Review 61, 485-501.

Güth, W., Königstein, M., Kovács, J., Zala-Mezõ, E., 2001. Fairness within firms: the case of one principal and many agents. Schmalenbach Business Review $53,82-101$.

Hannan, R.L., Kagel, J.H., Moser, D.V., 2002. Partial gift exchange in an experimental labor market: impact of subject population differences, productivity differences, and effort requests on behavior. Journal of Labor Economics 20, 923-951.

Hennig-Schmidt, H, Rockenbach, B., Sadrieh, A., 2010. In search of workers' real effort reciprocity-a field and a laboratory experiment. Journal of the European Economic Association 8, 817-837.

Herrmann, B., Thöni, C., 2009. Measuring conditional cooperation: a replication study in Russia. Experimental Economics 12, 87-92.

Konow, J., 2000. Fair shares: accountability and cognitive dissonance in allocation decisions. American Economic Review 90, $1072-1091$.

Kube, S., Maréchal, M.A., Puppe, C., 2010. The currency of reciprocity-gift-exchange in the workplace. Working Paper No. 377, Institute for Empirical Research in Economics, University of Zurich.

Leonard, J.S., 1990. Executive pay and firm performance. Industrial and Labor Relations Review 43, S13-S29.

Loewenstein, G., Thompson, L., Bazerman, M., 1989. Social utility and decision making in interpersonal contexts. Journal of Personality and Social Psychology $57,426-441$.

Maximiano, S., Sloof, R., Sonnemans, J., 2007. Gift exchange in a multi-worker firm. Economic Journal 117, 1025-1050.

Mittone, L., Ploner, M., 2009. Social effects in a multi-agent investment game: an experimental analysis. CEEL Working Paper, University of Trento.

Muller, L., Sefton, M., Steinberg, R., Vesterlund, L., 2008. Strategic behavior and learning in repeated voluntary-contribution experiments. Journal of Economic Behavior \& Organization 67, 782-793.

Selten, R., 1967. Die Strategiemethode zur Erforschung des eingeschränkt rationalen Verhaltens im Rahmen eines Oligopolexperimentes. In: Sauermann, H. (Ed.), Beiträge zur experimentellen Wirtschaftsforschung. J.C.B. Mohr (Paul Siebeck), Tübingen, pp. 136-168.

Sobel, J., 2005. Interdependent preferences and reciprocity. Journal of Economic Literature 43, 392-436.

Thöni, C., 2009. Social Learning, Comparison and Interaction: An Experimental Approach. Südwestdeutscher Verlag für Hochschulschriften, Saarbrücken.

Thöni, C., Gächter, S., 2010. Social preferences and peer effects in voluntary cooperation. CeDEx Discussion Paper, University of Nottingham.

Thöni, C., Tyran, J.-R., Wengström, E., 2009. Microfoundations of social capital. Discussion Paper No. 09-24, Department of Economics, University of Copenhagen.

Winter-Ebmer, R., Zweimüller, J., 1999. Intra-firm wage dispersion and firm performance. Kyklos 52, 555-572. 